\title{
Two Faces of a Coin: international trade and debt
}

\author{
Martin Wolf
}

Trade and debt are simply two faces of one coin. All debt represents a deferred claim on goods and must ultimately be repaid by the transfer of goods from debtors to creditors. International debt, more specifically, represents deferred international trade. The transfer of goods must take the form of a real trade surplus, if the aim is to cover the real interest on international debt, and of a real current account surplus, if the aim is to repay debt. It follows that, unless there are offsetting changes in the balance on factor services or in the capital account, adjustment to a change in either the availability of external capital or in interest rates must necessarily take the form of an alteration in the trade balances of both debtor and creditor countries.

These simple facts underlie the relation between trade and debt. Adjustment to a declining willingness to lend or to higher interest rates involves acceptance by creditors of a reduced trade surplus and by debtors of a reduced deficit. The trade positions of creditor and debtor countries may even switch. These adjustments in trade balances can be painful. They will be more painful the more they are resisted and the more inefficiently they are carried out. The ability to carry out the required adjustments in a reasonably smooth and harmonious manner is, therefore, a necessary (although not a sufficient) condition for a resolution of what has come to be called 'the debt crisis'.

Adjustments in trade balances involve trade policy in two respects. In the first place, adjustments need to occur not only in the overall balance between expenditure and output in both creditor and debtor economies but also in the composition of their output and expenditure. For these processes to work reasonably well, economies must be able to shift from one activity to another in a flexible manner. In the case of debtor countries, in particular, it is important that reductions in domestic expenditures lead readily to increased exports. Otherwise, adjustment will tend to occur in the most inefficient possible way, via import compression alone. Protection is, however, not only a prime source of economic inflexibility, but is also an indirect tax on exports. Those indebted economies which are highly protected will, therefore, prove unable to adjust effectively.

In the second place, trade policy in the major markets of the world, which are also the domiciles of the major creditor institutions, will determine the way in which the external adjustment - that is, the transfer of resources from debtor to creditor countries - is made. If the reduction in the trade deficits of the debtor countries is to occur in a reasonably efficient manner, these countries must achieve both export expansion and import reduction. Creditor countries must, therefore, accommodate the increased exports from indebted countries. If the latter cannot expand their exports because of protection abroad, they can service debt only by compression of imports. The resulting domestic economic disruption and resentment against the creditor countries will make maintenance of a cooperative approach to the task of servicing debt very difficult indeed, if not altogether impossible.

In the present analysis it is assumed that voluntary lending sufficient to finance previous trade deficits is no longer available, while coerced lending is neither a long term solution nor, in any case, equal in amount to previous voluntary lending. Consequently, adjustments to trade balances are necessary and inevitable. In other words, a 'real' solution to the problem of international indebtedness is required. A 'real' solution involves accommodation by creditor countries and export expansion by debtor countries. Failing both, there will be stagnation in debtor countries and perhaps even cumulative deflation in the world economy. In such circumstances, it will be recognised in time that the financial claims on the debtor countries' economies are of little value. While indebted countries may be willing to transfer resources to their creditors year after year - although even this can be doubted - they are far less likely to do so if the price is a sustained depression in their economies. 
In order to elaborate these points, the discussion below i) explains the nature of the debt service problem; ii) points out the defects in the present adjustment process and the implications for trade; iii) emphasises the need for faster growth in the world economy; iv) stresses the damaging effects of the widespread distortions in the market process; and $v$ ) argues that improved trade policy is needed in both creditor and debtor countries, in order to make faster growth and efficient adjustment feasible.

\section{Nature of the Debt-service Problem}

Credit, as the origin of the word suggests, derives from faith. Correspondingly, a credit crisis is a crisis of confidence, a situation in which faith in the fulfilment of obligations can no longer be taken for granted. In the current situation, however, confidence on the side of both the creditors and the debtors has deteriorated, which is to say the willingness to supply credit voluntarily has contracted. On both sides there has indeed been ample room for the growth of mutually compounding suspicions. Bankers, for their part, know that the debtors face strong domestic pressures against transfers of resources abroad over the long term; meanwhile, many citizens of indebted count ries feel that banks pulled the rug from under them in 1982 or even that the problem has been created almost entirely by the policies of key developed countries.

Credit is a borrowed or, put another way, a temporary command over real resources. The only real resources available for lending are that portion of current earnings which the persons (individuals and enterprises) who earned them have decided, for the time being, not to consume; in short, the only real resources available for lending are current savings.

Since the late 1970s the savings available for productive investment have been declining as a proportion of world income, because of the growth of budget deficits in both developed and developing countries and also because of the disappearance of the OPEC surplus. There is now, in effect, increased competition for a smaller amount of savings. In addition, there are fears about the inflationary consequences of large budget deficits. These fears themselves raise the apparent real rate of interest on long-term lending because current rates of inflation are lower than those expected in the future. Furthermore, uncertainty about the course of policies may itself increase the risk premium in long-term rates of interest, while tight monetary policy will tend to raise the opportunity cost of illiquidity.

To the change in nominal and real interest rates within developed countries must be added the appreciation of the dollar (in which some two-thirds of developing country debt is denominated) and the deterioration in the terms of trade of many developing countries. Because of the interaction of these effects, real interest rates for some developing countries rose to over 15 per cent in the early 1980s - levels at which merely borrowing to re-finance interest puts ratios of debt to gross domestic product (GDP) and to exports on explosive paths.

The intensity of the competition for available savings and high rates of interest has three implications for developing countries.

First, it implies that, if new capital is to be obtained on a sustained basis, developing countries will have to find projects offering higher returns than many have offered in the past.

Secondly, a significant portion of outstanding debt will have to be serviced out of current income, it now being far more difficult to find new capital to cover debt service payments. Until the end of the 1970s, by way of cont rast, most debtors were able to obtain new borrowings sufficient not only to re-finance outstanding principal but also to cover interest payments. Moreover, because of low real rates of interest and rapid real growth in export revenues, developing countries could borrow to cover debt service and still have improving debt-service ratios. It was therefore unnecessary for them to service debt out of current income. Indeed, with the interest rates of the 1970s it was hard to owe too much - or so it seemed at the time.

Finally, the rise in real rates of interest means that the burden of servicing the large outstanding debt out of current income is higher than it would have been previously.

It is the need to service debt out of current income combined with the high cost of doing so at current real rates of interest that is at the heart of what is called the 'debt crisis'.

In the right economic circumstances, developing countries should be able to find many projects that offer high returns. The immediate question, though, is how to service debt in the most efficient way, on the assumption that new borrowing will no longer be available in sufficient quantity to render unnecessary the task of servicing debt out of current income.

When facing up to the task, many developing countries are handicapped by the uses to which borrowed funds were put in the past. Thus a part of the outstanding debt was borrowed by governments to finance current expenditure or by state industrial enterprises for covering current operating deficits. It 
has been consumed. Indeed, in some developing countries the ratio of the public sector deficit to GDP has been as high as 15 per cent. At the same time, at least in many Latin American countries, borrowing abroad was accompanied by relatively large outflows of domestic capital - especially in the early 1980s. While governments and public-sector institutions are responsible for servicing gross indebtedness, the foreign-currency earnings of the assets held abroad are not available to them for debt-service purposes, unless their owners can be induced to repatriate them. To the extent, then, that borrowed resources have been consumed or offset by private outflows, the stock of debt does not itself generate the income from which it can be serviced. To service the deadweight debt, either other income has to be found, chiefly by taxing other activities, or governments must take those actions that will restore the confidence of their citizens and so induce the repatriation of assets held abroad.

The servicing problem of the debtor countries can be analysed, conceptually, in two parts. The debtcarrying entities must produce a surplus in their current operations equal to the amount of debt service (less any new credit obtained). This first stage may be called the domestic-currency equivalent of debt-service charges. To service foreign debts, however, domestic resources must be translated into foreign exchange for remittance to the creditors. This second stage may be called the transfer problem. Both aspects have been creating difficulties.

\section{Defects in the Present Adjustment Process}

That the internal adjustment of debtor countries would be painful was inevitable. The combined current account deficit of developing countries in 1982 of $\$ 100$ bn was equal to about 3.5 per cent of their combined GNP, but after removing some large countries with modest debt like India and China the ratio was over 5 per cent. For some of the larger Latin American debtors the ratios in 1981 ranged from 4.5 per cent for Brazil, to 5.5 per cent for Argentina, 8.0 per cent for Mexico and 16.5 per cent for Chile. Meanwhile, for South Korea the ratio was 6.5 per cent. The reductions in real expenditures in relation to output that are required to close - or even substantially reduce - such large current account deficits are substantial.

The need to reduce current account deficits in many indebted developing countries was the inevitable consequence of the decline in lending. Net disbursements of medium and long-term private loans to developing countries fell from $\$ 50$ bn in 1981 to $\$ 34$ bn in 1982, with most of the drop occurring in the second half of the year. In the first quarter of 1983 net private lending was only $\$ 2.6$ bn and most of this consisted of involuntary lending under the auspices of IMF rescheduling agreements.

On the internal side, the required adjustments to this sharp decline in lending have taken two forms: an overt attempt to reduce the size of the public sector deficit and a de facto increase in taxation through a rise in the inflation tax. The attention paid to public sector deficits is inevitable, since they tend to be reflected almost automatically in current account deficits in the balance of payments. It is possible that the private sector, representing often the smaller part of the economy, could produce a surplus which more than offsets the public sector deficit, but very strong pressure on expenditure by the private sector would then be required.

In practice, it has been impossible to avoid adverse effects on the private sector. Quite apart from higher taxes, there has also been a tendency towards accelerated inflation. Indeed, the acceleration in inflation that has occurred in a number of the principal debtor countries is not an accident. It is one way for existing public sector deficits to be financed. Closing the deficits by increased taxation (whether overt or covert) has, in turn, tended to lead to a squeeze on the private sector with potentially serious consequences for long-term investment and growth.

Theoretically, the closing of internal deficits, however painful in itself, should be translated smoothly into an improvement in the current account balance. In this sense the 'transfer problem' is secondary. Indeed, the external aspects of the transfer do not look to be anything like as daunting as the required internal adjustments. For the developed countries increased absorption of $\$ 100$ bn worth of goods and services would be needed to offset the elimination of the entire nominal deficit of developing countries (while avoiding deflation). Such an increase in absorption implies an expansion of total expenditures in their economies of only just over one per cent. Moreover, the output of tradeable goods and services in the developed countries need contract by no more than about 2 per cent, other things being equal, to effect the transfer. Indeed, in the context of economic recovery no overall shrinkage of these industries would appear to be necessary.

Nevertheless, the external transfer is not proceeding smoothly, with the result that the internal adjustment is turning out to be still more painful than might, in any case, be expected. There are two principal reasons for this, both of which are related to the difficulty the indebted countries are having in expanding exports. One reason is the high levels of protection in many of the indebted economies themselves, a protection which has actually tended to increase as stringent 
programmes to curb imports have been introduced on an emergency basis. The result is that the profitability of production for export, already low, has tended to decline still further. A second reason, not unrelated to the first, is that a substantial proportion (depending on the country) of the exports of debtor countries face restrictions and other obstacles in foreign markets, these usually being concentrated against the exports of industries in which the debtor countries have the greatest comparative advantage. 'Pushing out exports' against such resistance in foreign countries calls for the exertion of great pressure. Furthermore, even the fear of such barriers leads indebted countries to despair of success with exports and to introduce inward-looking policies that tend to make the prophecies of export gloom self-fulfilling.

Because of the difficulty in expanding exports, imports are cut instead. But many of the imports of developing countries are intermediate or investment goods; that is, they are essential inputs into current or future production. Hence, as a result of the need simply to adjust expenditures in relation to output, there is also a large loss of both present and future output. That loss of output then makes necessary a still sharper reduction in expenditures than would otherwise be necessary. This is why adjustment through the expansion of exports, which would allow fuller use of existing capacity and so tend to expand output, is so much more desirable than adjustment through the contraction of imports, which in most developing countries means the reverse.

In the context of the declining availability of external capital, developing countries have, willy nilly, improved their trade balances since 1982. In oilimporting developing countries the current account deficit (excluding official transfers) fell from $\$ 82$ bn in 1981 to $\$ 66$ bn in 1982 and an estimated $\$ 46$ bn in 1983. For oil-exporting developing countries the deficit fell from $\$ 32$ bn in 1982 to an estimated $\$ 10$ bn in 1983. Indeed, the combined deficit in 1983 was only a little larger than the interest due in that year.

This performance has been impressive, but costly. Unfortunately, evidence suggests that, to date, much of the adjustment has emphasised the reduction of imports. In many countries these improvements have, in other words, resulted largely from cutting imports relative to output and from recession-induced reductions in demand for imports. Imports were cut in real terms by about half in Argentina in 1982, by about 40 per cent in Mexico in 1982, by 30 per cent in Venezuela in 1983, and progressively by about 33 per cent between 1980 and 1983 in Brazil. In Brazil imports as a proportion of GDP fell from 6 to 4.6 per cent between 1980 and 1983 and in Chile from 30.4 to 21.3 per cent. In many cases imports have been cut to the point where they consist only of industrial raw materials and essential foodstuffs with little even for investment.

Only a few countries have managed to expand exports sufficiently to avoid serious domestic recession. Korea and Turkey, for example, had sizable foreign debts; but by following effective adjustment policies, they succeeded in expanding both their real imports and exports during the $1980 \mathrm{~s}$. By contrast, the real value of exports declined in Argentina and Venezuela between 1981 and 1983 and was stagnant in Brazil.

In short, the present adjustment process involves large and inevitable cuts in real expenditures in developing country debtors. These cuts have had to include reductions in public sector expenditures. The problem is that these cuts are going only in part into improvements in the balance of payments and are having a large depressing effect on domestic economies. A major reason is the failure to expand exports, partly because of external resistance to such exports but mainly because of the consequences for exports of domestic protection. The main result of this inefficient pattern of adjustment has been sharp and increasingly politically intolerable - reductions in consumption per caput in many indebted countries. In 1982, for example, consumption per caput fell by 10 per cent in Argentina, by 6 per cent in Mexico, and by 3 per cent in Brazil.

\section{Need for Sustained Growth}

How, then, is the problem of developing country debt to be resolved in the least painful and most efficient way? 'In the context of a vigorous and sustained recovery in the world economy' is the obvious answer. What difference would that make?

Whatever the international environment, those governments which have used past borrowing to support an overvalued rate of exchange and an inefficient domestic policy regime must now retrench. Moreover, those adjustments must include not only a reduction in public-sector deficits but also measures to improve efficiency in the use of resources. It is only in this way that the consequences for production present and future - of reductions in expenditure can be minimised and that renewed borrowing for investment will be justified. Hence debtors should be discouraged from 'adjusting' by imposing greatly increased burdens on the private sector (by raising the inflation tax, for example) or by attempting to 'save foreign exchange largely by reducing imports via import controls. At best, the two actions are immensely costly ways of adjusting; and, at worst, they make adjustment ultimately impossible. 
Even so, in a sluggish world economy, debtor countries are all too likely to service their current debt by maintaining severe macroeconomic pressure and imposing import restrictions, with economic stagnation, widespread unemployment and political unrest resulting as a matter of course. This is not a politically sustainable course.

In the past two years, the IMF has probably been the most important interlocutor between the creditor countries and the debtor countries, forced into trying single-handedly to make good debtors out of bad ones, with the creditors themselves not under effective pressure to change any significant aspect of their own behaviour, except by providing the IMF with more money. There is no doubt that the IMF is an invaluable instrument. But it may be overwhelmed by current expectations of its role. What is missing inter alia is a willingness on the part of creditor countries to change their policies.

The essential point is that, if the world economy were again to grow in a sustained way, the problems facing the debtor countries would be substantially eased.

First, prices and volumes of export commodities would rise, which would be directly beneficial for both their national income and public revenue.

Secondly, provided faster growth in the world economy was accompanied by diminished protectionism (as it would probably have to be if the increased rate of growth was to be maintained), improved access to markets would give their exports a more permanent boost, greatly increasing the likelihood that the debtor countries would be able to adjust through efficient expansion of exports.

Their rate of growth would then be higher and, with higher growth of national income and exports, they could borrow more. In this context, it should be remembered that as long as the real rate of interest on borrowing is lower than the growth of the debtor's national income, a continued net capital inflow is consistent with stability in the ratio of debt to GNP. In spite of continued high real rates of interest, therefore, the prospect of a return to rapid growth in the debtor countries, following the required retrenchment in the short term, would play a part in restoring their creditworthiness and relieving pressure both on them and on the creditor institutions.

\section{Restoring the Price System}

The current recovery in the United States will not of itself solve the problem unless followed by the adoption of policy measures to raise economic growth in the world economy as a whole over the longer term.
The debtor countries should not be the only ones encouraged to undertake such measures, for in microcosm, although in extreme form, their problems are those of the world economy at large.

The widespread distortions and rigidities in national price systems, and hence the impairment of the international price system, can persist only to the extent that national economies are shielded by protection from pressures emanating in world markets. In its annual report for 1982/83 the GATT secretariat has actually asked what is left of the price mechanism. The report points out that all studies indicate that protectionism has been steadily increasing. Given the growth of subsidies and regulation, there can be little surprise that what investment is taking place appears not to be yielding the fruit expected. A long-term tendency to low growth reflects persistent economic waste.

Such have been the domestic circumstances in which the adherence of governments to GATT principles and rules has been steadily weakening for nearly two decades. In the early 1970s, governments began reaffirming, in one declaration after another, their commitment to GATT principles and rules. But they continued to feel obliged to make exceptions to the rules, always for reasons which seemed plausible in the short term, hoping no doubt to maintain the integrity of the rules as a whole in the longer term.

Increasing resort to non-tariff measures has undermined the force of GATT rules. But worse, the GATT system per se has been undermined by the increasing resort to extra-GATT means of protecting industries unable to cope with foreign competition, these chiefly being 'voluntary' export restraint agreements, negotiated bilaterally and euphemistically referred to as 'informal' or 'grey area' measures. Through them and other non-tariff measures, notably sector-specific subsidies, separate extra-GATT systems of protection have been developed for entire industries, including agriculture, textiles and clothing, shipbuilding, steel and automobiles.

\section{Towards a Long-term Solution}

What is required from the rest of the world in order to accominodate and facilitate the necessary efforts to adjust in the debtor countries? In the short term, rescheduling of existing debt, official provision of new credit and encouragement to commercial banks to keep lending with all be needed, largely in order to buy time. A permanent solution, however, demands changes on the 'real' side of the world economy, most of all accelerated economic growth and an increased ability in the rest of the world to accommodate the efforts being made by the debtor countries themselves 
to service their debts through increased export earnings.

The best policy for achieving both higher growth and improved accommodation of imports is the vigorous pursuit of trade liberalisation. Ultimately, a credible programme of trade liberalisation must change rigid economic structures, abolish outmoded ways of doing business and thereby increase flexibility in labour and capital markets, for in an open economy there is simply nowhere for the inefficient to hide.

The international debt situation demands prompt action. While the preparation for a global trade initiative continues, it should be possible to start a negotiating process in which developing countries can seek immediate action on tariffs and non-tariff measures which inhibit their exports to developed countries, while offering the possibility of action on their own tariffs and import controls. The achievement of 'transparency' in trade restrictions is an objective that should be pursued at the same time. Such negotiations under GATT auspices would require first of all the active involvement of the debtor countries and their principal trading partners, but under the GATT's provisions and multilateral procedures the negotiations would be open to other GATT members countries, with whatever 'concessions' that were agreed being extended on a most-favoured-nation basis to all GATT member countries.

There can be no minimising the difficulty of launching such a trade negotiation. Many of the developing countries that are having difficulty servicing their debts are efficient producers and exporters of products which are heavily supported and protected in many of the creditor countries (eg agriculture, textiles and steel). Moreover, both the developing countries that are having difficulty servicing their debts and the other developing countries - including those in danger of encountering debt-service problems - which are adversely affected by the protectionist and discriminatory policies of developed countries are only going to be persuaded about the merits of such a trade negotiation if it is expected to yield improved access to markets, improved security in trade flows and improved prospects for economic development.

On the question of a global trade initiative, the developed countries need to examine more rigorously than they have to date the possibilities for action on specific issues of special concern to developing countries, such as the tendencies to discriminate against the more successful among them and to develop sectoral systems of protection. At the same time, the developing countries need to generate a greater appreciation of the benefits for their economic development that could result from a readiness on their part to liberalise their trade regimes.

Meanwhile, liberalisation by debtor countries should in any case be an essential element in every debt-relief negotiation, since the more distorted their domestic policy regimes the less probable it is that they will develop the kinds of high-return investments and achieve the sort of export growth which will again make them creditworthy in the long run.

Austerity is not enough. Changes are needed that hold out hope to the debtor countries of renewed economic growth and renewed borrowing. What is needed, therefore, is a restoration of the proper functioning of the market mechanism in both developed and developing countries. This would follow automatically from measures to liberalise trade and eliminate sectorspecific subsidies. Stabilisation without liberalisation is likely to yield stagnation; and in such a world, international cooperation would not endure. Measures to restore the efficiency of the real economy, through trade liberalisation, are at the heart of any long-term resolution of the debt crisis. 